\title{
Pengaruh disiplin kerja terhadap kinerja guru
}

\section{(The influence of work discipline on teacher performance)}

\author{
Kania Teja Utari', Rasto ${ }^{*}$ \\ ${ }^{1,2}$ Program Studi Pendidikan Manajemen Perkantoran, \\ Fakultas Pendidikan Ekonomi dan Bisnis, Universitas Pendidikan Indonesia \\ JI. Dr. Setiabudhi, No. 229 Bandung, Jawa Barat Indonesia \\ Email: rasto@upi.edu
}

\begin{abstract}
ABSTRAK
Penelitian ini bertujuan untuk menganalisis pengaruh disiplin kerja terhadap kinerja guru. Metode penelitian menggunakan metode survey. Teknik pengumpulan data menggunakan angket model rating scale. Responden adalah 45 guru Sekolah Menengah Kejuruan Swasta di Kota Cimahi. Teknik analisis data menggunakan analisis regresi. Hasil penelitian menunjukkan disiplin kerja memiliki pengaruh positif dan signifikan terhadap kinerja guru. Oleh sebab itu, kinerja guru dapat ditingkatkan melalui peningkatan disiplin kerja.
\end{abstract}

Kata Kunci: Disiplin Kerja; Kinerja Guru

\begin{abstract}
This study aimed to determine the influence of work discipline on teacher performance. The research method used survey. Data collection technique used questionnaire rating scale models. Respondents are 45 teachers of Vocational High School in Cimahi. Data were analyzed using regression. The results of the study revealed that work discipline have a positive and significant influence on teacher performance. Therefore, performance of teacher can be improved though improving work discipline.
\end{abstract}

Keywords: Work Discipline; Teacher Performance

\section{PENDAHULUAN}

Guru memiliki peran penting dalam mengembangkan sumber daya manusia melalui proses pendidikan (Cintamulya, 2015; Mahmudah \& Sarino, 2016; Hussain, Ahmed, \& Haider, 2014; Koswara \& Rasto, 2016; Susanto, 2012). Guru merupakan aset utama yang berperan sebagai pilar dan ujung tombak pelaksanaan sistem pendidikan, karena guru merupakan pihak yang paling banyak bersentuhan langsung dengan siswa dalam proses pembelajaran (Aslam, 2012; Anggraeni \& Rasto, 2016; Srinalia, 2015). Oleh karena itu kinerja guru yang optimal menjadi salah satu faktor penting dalam mewujudkan pendidikan yang berkualitas (Pudjiastuti \& Sriwidodo, 2011).

Received: Februari 2019, Revision: Mei 2019, Published: Juli 2019 
Hasil studi pendahuluan menunjukkan bahwa kinerja guru pada salah satu Sekolah Menengah Kejuruan di Kota Cimahi belum optimal. Melalui kajian perilaku organisasi, banyak faktor yang dapat mempengaruhi kinerja guru. Faktor disiplin kerja diduga memiliki pengaruh yang kuat terhadap kinerja guru. Berdasarkan hal tersebut, rumusan masalah penelitian ini adalah "adakah pengaruh disiplin kerja terhadap kinerja guru?" Dengan demikian tujuan dari penelitian ini adalah untuk menganalisis pengaruh disiplin kerja terhadap kinerja guru.

\section{TINJAUAN PUSTAKA \\ Kinerja Guru}

Secara umum kinerja dimaknai sebagai tindakan dan perilaku yang berada di bawah kendali individu yang berkontribusi terhadap tujuan organisasi secara legal yang tidak melanggar hukum serta tidak bertentangan dengan etika atau moral (Mangkuprawira dalam Roeleejanto, Brasit, Payangan, \& Pahlevi, 2015). Secara spesifik kinerja sering dimaknai sebagai hasil yang dicapai seseorang (Amstrong, 2010), baik secara kualitas maupun kuantitas sesuai dengan tanggung jawab yang diberikan kepadanya (Mangkunegara \& Waris, 2015) berdasarkan keterampilan, pengalaman, kemampuan dan waktu tertentu dengan kriteria atau standar tertentu (Nurwati, 2015; Febiningtyas \& Ekaningtias, 2014).

Kinerja guru merupakan gambaran hasil kerja yang dilakukan oleh guru (Uno, 2014), yang ditunjukkan guru dalam melaksanakan tugas dan tanggung jawabnya sesuai dengan profesinya (Syamra, 2016). Kinerja guru tercermin dalam pelaksanaan proses pembelajaran baik di dalam kelas maupun di luar kelas, administrasi sekolah, serta bimbingan dan layanan pada para siswa (Wijaya \& Rusyan, 1991).

\section{Disiplin Kerja}

Disiplin kerja merupakan salah satu elemen penting yang mempengaruhi kinerja guru. Disiplin adalah kesediaan seseorang yang timbul dengan kesadaran sendiri (Handoko dalam Sinambela, 2012), sebagai rasa hormat, taat, dan mematuhi peraturan yang berlaku, baik tertulis maupun tidak tertulis (Itang, 2015). Disiplin tercermin dalam tindakan atau perilaku individu, kelompok, atau masyarakat dalam bentuk ketaatan atau kepatuhan terhadap peraturan yang ditetapkan (Sinungan dalam Elqadri, Wardoyo, \& Priyono, 2015). Disiplin pegawai dapat dilihat dari tanggung jawab, sikap, perilaku dan tindakan seorang karyawan sesuai dengan segala bentuk regulasi selama mereka bekerja di lembaga tersebut (Febiningtyas \& Ekaningtias, 2014).

Disiplin sebagai proses mengarahkan atau mengendalikan kepentingan yang digerakkan demi mencapai tujuan yang mengarah pada tindakan yang lebih baik (Tumilaar, 2015) serta untuk meningkatkan dan membangun pengetahuan, sikap dan perilaku guru sehingga guru secara sukarela menaati pekerjaan (Siagian dalam Elqadri, Wardoyo, \& Priyono, 2015). Disiplin kerja adalah suatu alat yang digunakan para atasan (Wardoyo, 2015) sebagai prosedur untuk mengoreksi atau menghukum bawahan karena melanggar peraturan (Turang, Kindangen, \& Tumiwa. 2015) Penegakan disiplin dapat mengatasi masalah kinerja yang buruk dan memperkuat pengaruh perilaku kerja pegawai dengan kelompok atau organisasi. Apabila disiplin dapat dilaksanakan secara baik serta tidak menunda waktu maka masalah yang terjadi dapat diatasi secara cepat dan mudah (Liden, Wayne, \& Kraimer, 2001).

Berdasarkan tinjauan pustaka sebagaimana dipaparkan di atas, dapat digambarkan theoretical framework seperti berikut: 


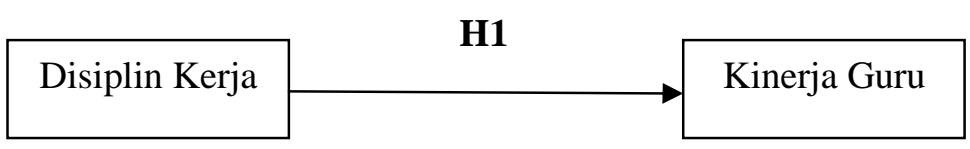

\section{Gambar 1 Theoretical Framework}

$\mathrm{H} 1$ = terdapat pengaruh disiplin kerja terhadap kinerja guru

\section{METODOLOGI}

Metode yang digunakan dalam penelitian ini adalah metode survey. Alat pengumpulan data menggunakan kuesioner model rating scale, yang terdiri atas dua bagian. Bagian pertama adalah angket yang digunakan untuk mengukur disiplin kerja, terdiri atas empat indikator yaitu kesadaran, kesediaan, kepatuhan dan etika kerja. Bagian kedua adalah angket untuk mengukur kinerja guru, yang terdiri atas lima indikator yaitu kerja, ketepatan kerja, inisiatif dalam kerja, kemampuan kerja dan komunikasi. Responden dalam penelitian ini adalah guru Sekolah Menengah Kejuruan Swasta Kota Cimahi, Provinsi Jawa Barat sebanyak 45 orang. Statistik deskriptif digunakan untuk mengetahui gambaran persepsi responden tentang disiplin kerja dan kinerja guru, yang diperoleh melalui skor rata-rata. Statistik inferensial digunakan untuk mengetahui pengaruh disiplin kerja terhadap kinerja guru yang diperoleh melalui regresi sederhana.

\section{HASIL PENELITIAN DAN PEMBAHASAN}

\section{Kinerja Guru}

Kinerja guru diukur melalui lima indikator, yaitu kualitas kerja, kecepatan dan ketepatan, inisiatif dalam bekerja, kemampuan kerja, dan komunikasi (Uno \& Lamatenggo, 2012). Kualitas kerja merupakan hasil kerja guru yang meliputi aspek ketelitian dan keterampilan. Kecepatan/ketepatan kerja meliputi ketepatan guru menyelesaikan program pengajaran sesuai kalender akademik, ketepatan guru melaksanakan proses pembelajaran sesuai dengan Rencana Pelaksanaan Pembelajaran, ketepatan guru menggunakan media pembelajaran, dan ketepatan guru memberikan materi ajar sesuai karakteristik peserta didik. Inisiatif dalam kerja berkaitan dengan semangat guru dalam menyelesaikan tugas-tugasnya serta kemampuan dalam mengambil resiko dan membuat suatu keputusan yang baik tanpa adanya pengarahan terlebih dahulu dari atasan. Kemampuan kerja meliputi penggunaan metode pembelajaran yang variatif, pemahaman dan pelaksanaan fungsi serta tugas guru di sekolah, kemampuan guru melaksanakan layanan bimbingan, serta kemampuan guru menerapkan hasil penelitian terhadap pembelajaran. Komunikasi berkaitan dengan efektivitas komunikasi guru dengan internal dan eksternal sekolah.

Kinerja guru menurut persepsi responden berada pada kategori tinggi, sebagaimana ditunjukkan oleh skor rata-rata jawaban responden sebesar 3,76. Tabel 1 menyajikan skor rata-rata dari masing-masing indikator yang dijadikan ukuran kinerja guru. 
Tabel 1.

Kinerja Guru

\begin{tabular}{|l|c|c|}
\hline \multicolumn{1}{|c|}{ Indikator } & Rata-rata & Penafsiran \\
\hline Kualitas Kerja & 3.94 & Tinggi \\
\hline Ketepatan Kerja & 3.59 & Tinggi \\
\hline Inisiatif dalam Kerja & 3.81 & Tinggi \\
\hline Kemampuan Kerja & 3.83 & Tinggi \\
\hline Komunikasi & 3.62 & Tinggi \\
\hline Rata-rata & $\mathbf{3 . 7 6}$ & Tinggi \\
\hline
\end{tabular}

Skor tertinggi berada pada indikator kualitas kerja. Hasil ini menunjukkan bahwa guru telah menunjukkan kinerja yang tinggi dalam mepersiapkan perencanaan program pengajaran, mengelola kegiatan belajar mengajar, penguasaan materi ajar, dan pemenuhan adimnistrasi pembelajaran. Skor terendah berada pada indikator ketepatan kerja. Hasil ini menunjukkan kinerja guru dalam penyelesaian program pengajaran sesuai kalender akademik, pelaksanaan proses pembelajaran sesuai dengan rencana pembelajaran, penggunaan media pembelajaran, dan penyampaian materi ajar sesuai dengan karakteristik peserta didik masih belum optimal.

\section{Disiplin Kerja}

Disiplin kerja diukur melalui empat indikator, yaitu kesadaran, kesediaan, kepatuhan, dan etika kerja (Hasibuan, 2006). Kesadaran merupakan sikap guru untuk secara sukarela menaati semua peraturan. Kesediaan, merupakan suatu sikap, tingkah laku dan perbuatan guru sesuai dengan peraturan baik tertulis maupun tidak tertulis. Ketaatan, merupakan tindakan yang dilakukan guru sesuai perintah tanpa mengeluh. Etika merupakan aturan mengenai tingkah laku dan nilai dalam kehidupan sehari-hari ketika bekerja.

Disiplin kerja guru menurut persepsi responden berada pada kategori tinggi, sebagaimana ditunjukkan oleh skor rata-rata jawaban responden sebesar 3,82. Tabel 2 menyajikan skor rata-rata dari masing-masing indikator yang dijadikan ukuran disiplin kerja guru.

Tabel 2.

Disiplin Kerja

\begin{tabular}{|l|c|c|}
\hline \multicolumn{1}{|c|}{ Indikator } & Rata-rata & Penafsiran \\
\hline Kesadaran & 4.00 & Tinggi \\
\hline Kesediaan & 3.84 & Tinggi \\
\hline Kepatuhan & 3.56 & Tinggi \\
\hline Etika Kerja & 3.89 & Tinggi \\
\hline Rata-rata & $\mathbf{3 . 8 2}$ & Tinggi \\
\hline
\end{tabular}

Skor tertinggi berada pada indikator kesadaran. Hasil tersebut menunjukkan guru telah memiliki kesadaran yang tinggi terhadap tanggung jawab pekerjaan dan sanksi hukuman sebagai konsekuensi dari kedisiplinan. Skor terendah berada pada indikator kepatuhan. Hasil ini menunjukkan kepatuhan guru untuk bekerja sesuai jam yang telah 
ditentukan, kepatuhan guru untuk hadir tepat waktu di sekolah, kepatuhan guru dalam melaksanakan tata tertib sekolah, kepatuhan guru untuk bekerja sesuai fungsi dan tugas yang telah ditentukan, dan kepatuhan guru dalam memberikan hasil pekerjaan sesuai dengan aturan yang telah ditentukan belum optimal.

\section{Pengaruh Disiplin Kerja terhadap Kinerja Guru}

Hasil pengolahan data diperoleh persamaan regresi linier sederhana untuk hipotesis variabel disiplin kerja terhadap variabel kinerja guru adalah $\hat{Y}=23,298+$ $0,739(\mathrm{X})$ dengan konstanta 56,56. Tanda positif (+) menunjukkan hubungan antara variabel bebas dengan variabel terikat berjalan satu arah, sehingga apabila semakin tinggi disiplin kerja guru maka semakin tinggi pula kinerja guru, begitupun sebaliknya. Uji signifikansi menggunakan uji t. Berdasarkan hal tersebut diperoleh nilai thitung sebesar 3,1875 dan nilai $t_{\text {tabel }(0,05 ; 45-2)}$ sebesar 2,0181. Dengan demikian, nilai $t_{\text {hitung }}>$ nilai $t_{\text {tabel }}(3,1875>2,0181)$, maka $\mathrm{H}_{0}$ ditolak dan $\mathrm{H}_{1}$ diterima. Dengan hasil ini dapat disimpulkan bahwa "ada pengaruh disiplin kerja terhadap kinerja guru". Berdasarkan nilai koefisien determinasi, pengaruh disiplin kerja terhadap kinerja guru adalah sebesar $19 \%$ sedangkan $81 \%$ dipengaruhi oleh faktor-faktor lain yang tidak diteliti dalam penelitian ini.

Hasil ini memperkuat teori dan temuan-temuan dari penelitian sebelumnya mengenai pengaruh disiplin terhadap kinerja. Terdapat pengaruh yang positif dan signifikan dari disiplin kerja terhadap kinerja (Faradina \& Sojanah, 2018; Wardoyo, 2015; Roeleejanto, Brasit, Payangan, \& Pahlevi, 2015; Turang, Kindangen, \& Tumiwa, 2015). Secara teoretik kinerja seseorang salah satunya dipengaruhi oleh disiplin kerja (Siagian, 2010). Disiplin benar-benar memainkan peran penting dalam membentuk perilaku (Suci \& Idrus, 2015; Itang, 2015). Kinerja yang baik dipengaruhi oleh disiplin kerja yang baik (Permatasari, Musadieq, \& Mayowan, 2015). Disiplin kerja yang baik mencerminkan rasa tanggung jawab dari seorang terhadap pekerjaan yang diberikan kepadanya (Elqadri, Wardoyo, \& Priyono, 2015). Pegawai yang memiliki disiplin kerja tinggi, akan mampu menyelesaikan tugas dengan cepat dan tepat (Mailiana, 2016), karena disiplin sudah menyatu dengan dirinya, maka sikap atau perbuatan yang dilakukan sama sekali tidak dirasakan sebagai beban (Prihantoro, 2012) sehingga dapat meningkatkan kinerjanya (Pudjiastuti \& Sriwidodo, 2011). Dengan demikian, disiplin kerja berpengaruh terhadap kinerja pegawai (Tumilaar, 2015).

\section{KESIMPULAN}

Disiplin kerja yang tercermin dari kesadaran, kesediaan, kepatuhan dan etika kerja berpengaruh positif dan signifikan terhadap kinerja guru yang tercermin dari kualitas kerja, ketepatan kerja, inisiatif dalam kerja, kemampuan kerja dan komunikasi. Dengan demikian peningkatan disiplin kerja guru merupakan salah satu faktor krusial bagi peningkatan kinerja guru yang sangat dibutuhkan dalam melaksanakan pendidikan yang berkualitas. Tanpa kehadiran guru yang memiliki disiplin dan kinerja tinggi, kualitas pendidikan dipertaruhkan.

\section{DAFTAR PUSTAKA}

Armstrong, M. (2010). Armstrong's Essential Human Resource Management Practice: A Guide to People Management. Kogan Page Publishers. 
Anggraeni, R., Rasto, (2016). Job Satisfaction and Organizational Commitment as Determinants of Teacher Performance, The 1st Global Conference on Business, Management and Entreupreuneurship (GCBME-16), Advances in Economics, Business and Management Research, 15, 525-529.

Aslam, R. (2012). Investigating the Relationship of OCB with Job Satisfaction Organizational Commitment and Turnover Intensions. Management Journal, 1(9), 90-100.

Cintamulya, I. (2015). Peranan Pendidikan dalam Mempersiapkan Sumber Daya Manusia di Era Informasi dan Pengetahuan. Formatif: Jurnal Ilmiah Pendidikan MIPA, 2(2), 90-101.

Elqadri, Z. M., Wardoyo, D. T., \& Priyono. (2015). The Influence of Motivation and Discipline Work against Employee Work Prouctivity Tona'an Markets. Review of European Studies, 7 (12), 59-66.

Faradina, V. D., \& Sojanah, J. (2018). Meningkatkan Kinerja Pegawai Melalui Lingkungan dan Disiplin Kerja. Jurnal Pendidikan Manajemen Perkantoran, 1(2), 8-18.

Febiningtyas, R. E.R., \& Ekaningtias, D. (2014). The Effect of Leadership, Motivation, and Work Discipline on The Employees Performance of Finance Section in the Regional Working Unit in Tulungagung Regency. The Indonesian Accounting Review , 4 (2), 97-106.

Hasibuan, M. SP. (2006). Manajemen Sumber Daya Manusia. Jakarta: PT. Bumi Aksara.

Hussain, M. A., Ahmed, I., \& Haider, S. Z. (2014). Investigating the Relationship among Organizational Commitment, Job Satisfaction and Emotional Intelligence-Evidence from Teachers at Secondary Level in Pakistan. Journal of Education and Social Sciences, 2(2), 127-143.

Itang. (2015). Work Discipline and Work Competence with Quality of Service in the Office of Religious Affairs (KUA) District of Mount Kencana Lebak Regency of Banten. Journal of Management and Sustainability, 5 (3), 132-140.

Koswara, K., \& Rasto, R. (2016). Kompetensi dan Kinerja Guru Berdasarkan Sertifikasi Profesi. Jurnal Pendidikan Manajemen Perkantoran, 1(1), 64-74.

Liden, R. C., Wayne, S. J., \& Kraimer, M. L. (2001). Managing individual performance in work groups. Human Resource Management: Published in Cooperation with the School of Business Administration, The University of Michigan and in alliance with the Society of Human Resources Management, 40(1), 63-72.

Mahmudah, A. N. M., \& Sarino, A. (2016). Budaya Organisasi dan Motivasi sebagai Prediktor Kinerja Guru Sekolah Menengah Kejuruan. Jurnal Pendidikan Manajemen Perkantoran, 1(1), 1-10.

Mailiana. (2016). Pengaruh Disiplin Kerja terhadap Kinerja Pegawai Dinas Pengelolaan Pasar Kota Banjarmasin. Jurnal Ekonomi Manajemen , 10 (1), 123-134. 
Mangkunegara, A. P., \& Waris, A. (2015). Effect of training, competence and discipline on employee performance in company (case study in PT. Asuransi Bangun Askrida). Procedia-Social and Behavioral Sciences, 211, 1240-1251.

Nurwati. (2015). The Influence of Discipline and Competency toward Employees Performance. Proceedings Journal of Educatiom, Psychology and Social Science Research. 142-148.

Permatasari, J. A., Musadieq, M. A., \& Mayowan, Y. (2015). Pengaruh Disiplin Kerja dan Motivasi Kerja terhadap Prestasi Kerja Karyawan Studi pada PT BPR Gunung Ringgit Malang. Jurnal Administrasi Bisnis , 25 (1), 1-9.

Prihantoro, A. (2012). Peningkatan Kinerja Sumber Daya Manusia Melalui Motivasi, Disiplin, Lingkungan Kerja, dan Komitmen. Value Added| Majalah Ekonomi Dan Bisnis, 8(2), 78-98.

Pudjiastuti, E., \& Sriwidodo, U. (2011). Pengaruh Kompetensi, Disiplin Kerja, dan Kepuasan Kerja terhadap Kinerja SMP Negeri 1 Purwodadi Grobogan. Jurnal Sumber Daya Manusia, 5(2), 120-131.

Ruleejanto, C., Brasit, N., Payangan, O. R., \& Pahlevi, C. (2015). Effects of Leadership, Competency, and Work Discipline on the Application of Total Quality Management and Employees' Performance for the Accreditation Status Achievement of Government Hospitals in Jakarta, Indonesia. Scientific Research Journal (SCIRJ), 3(11), 14-24.

Siagian, S. P. (2010). Manajemen Personalia dan Sumber Daya Manusia. Jakarta: Bumi Aksara.

Sinambela, L. P. (2012). Kinerja Pegawai Teori Pengukuran dan Implikasi. Bandung: Alfabeta.

Srinalia, S. (2015). Faktor-faktor Penyebab Rendahnya Kinerja Guru dan Korelasinya terhadap Pembinaan Siswa: Studi Kasus di SMAN 1 Darul Imarah Aceh Besar. Jurnal Ilmiah Didaktika, 15(2), 193-207.

Suci, R. P., \& Idrus, M. S. I. (2015). The Influence of Employee Training and Discipline Work against Employee Performance PT. Merpati Nusantara Airlines (Persero). Review of European Studies, 7(11), 7.

Susanto, H. (2012). Faktor-Faktor yang Mempengaruhi Kinerja Guru Sekolah Menengah Kejuruan. Jurnal Pendidikan Vokasi , 197-212.

Syamra, Y. (2016). Pengaruh Kompensasi Finansial dan Motivasi Kerja Guru Terhadap Kinerja Guru SMK Negeri Pariwisata di Kota Padang. Jurnal Economica: Research of Economic and Economic Education, 4(2), 258-268.

Tumilaar, B. R. (2015). The effect of discipline, leadership, and motivation on employee performance at bpjs ketenagakerjaan Sulut. Jurnal EMBA: Jurnal Riset Ekonomi, Manajemen, Bisnis Dan Akuntansi, 3(2), 787-797. 
Turang, R. C., Kindangen, P., \& Tumiwa, J. (2015). Influence of Leadership Style, Motivation, and Work Discipline on Employee Performance in PT. Dayana Cipta. Jurnal Berkala Ilmiah Efisiensi, 15 (4), 505-516.

Uno, H. B. (2014). Teknologi Komunikasi \& Informasi Pembelajaran. Jakarta: Bumi Aksara.

Uno, H. B., \& Lamatenggo, N. (2012). Teori Kinerja dan Pengukurannya. Jakarta: Bumi Aksara.

Wardoyo, D. T.W. (2015). The Influence of the Discipline and Compensation againts Work Productivity (Study on the Security Services Company, PT. Garuda Milky Artha Surabaya. International Journal of Business and Management , 11 (1), 6471.

Wijaya, C., \& Rusyan, A. T. (1991). Kemampuan Dasar Guru dalam Proses Belajar Mengajar. Bandung: PT Remaja Rosdakarya. 